\title{
IV その他の産業
}

\section{1. 漁業 \\ 吉田敬 市*}

魞漁業 內水面漁業の特質をる牛農牛漁的經營により成立夏る野洲郡木 濱の魞漁業と野洲川下流の筑漁業について，その立地條件並に經營の特質 につ々て概要を報告する。本漁區は琵琶湖南岸に位し，湖東湖南兩漁區の 恰も潮移地帶に當る。又野洲川と對岸の真野川との湖脥部仗琵琶湖の根幹 部とその枝葉部との境界に當り, 水深・流速・水溫變化等に特殊愫を示し, ここに湖岸最大の魶漁業地帶が出現している.

魞漁業立地の主なる條件を舉げれば，（1）湖底は遠淺で砂泥質より成 り, 魞の建設に適していること。（2）水溫上景度が比較的大で，藻類が

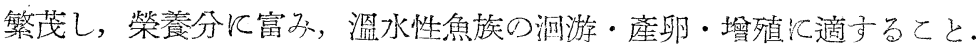

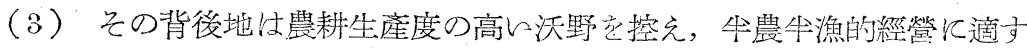
るとと・（4）漁獲物の販賣市場に接近し，資金尊入面に安全性と圓滑性 があるとと（5）建設資材の入手㤁容易で，勞衝源も豐であり，更に經 營面では古來優秀なる經驗と能力とを有するとと.

本地帶產の魚族はコイ，フナ，モロコ，八ス，ウナ乎等の溫水性のもの

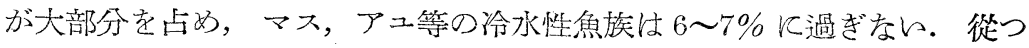
て此等溫水性魚族が，產卵のために湖岸に泪游する時が漁期となり，てて に魞・刺網・モンドリ等，各種の待受式漁法が必然的に發達した.

魞漁業の沿革・漁法等についてては，既飞報告がある柿ら(1)(2)，と〉で は主として經營の特質について述べるとと〉し花。本地帶は湖東平野に於 ける他表的度水田卓越地帶で，畑作の攄張豫地は極度に制約され，しが 平均一戶宛の耕作面積古古來 7 8 反で市るから, 米作依存の小規模經營 で注，生計の安定性が保持し難かつ灰。從つて現金收入の手段としては，

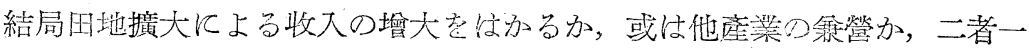
を選ぶ以外に方法は字いが，湖岸地帶では，多角的萦農業經營よりも，漁

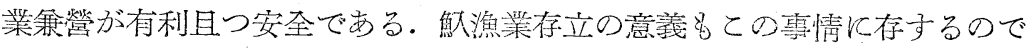

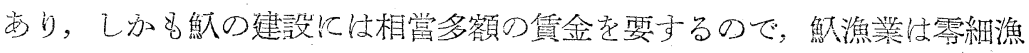
民の專業としては，成立し難いが，震業との組合せによる經管としては好 個の條件を具えている. 郎方賞地農家の現金收入は米の收蕒直後に集中し， 


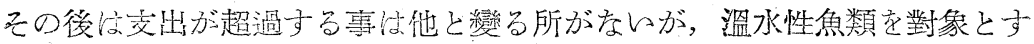
る魞漁業は惷夏の候が盛漁期で市り，その現金化が極めて圓滑飞行われる

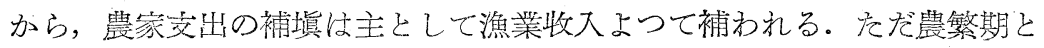
盛漁期とが重複する點が，單飞勞働力のみならず，耕作反別面積又は漁業

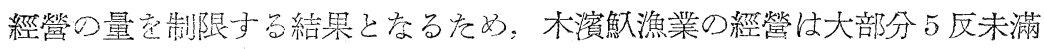
の零細農上中小農の一部によつて行方れる。

筑漁蓉 筑㴔業は滋賀縣では安量川流域が代表的であるが，野洲川では， 河口亦方上流約 $2 \mathrm{~km}$ の今濱橋を挾んで筑が敷設經營されている. 久の資

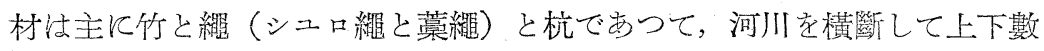
ろ所に設ける。筑は古くから見られる最も原始的な漁法で㐫るが，今日で

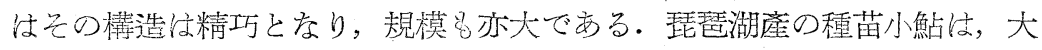
部分此等湖岸地帶諸川の筑によつて採捕し忘もので, 我國淡水魚種苗界儿 於ける重要意義を有する。

本漁業㤃只性質上，流水量と密接学關係があり，特に野洲川の場合は， 野洲川の性格から來る自然的諸條件に大々に左右され，從つて危險性梠件 ら漁業である。を種苗小鮎の供給範圍が殆ど全國的である關係上，その 賣上代金の包收が遲延するのが普通であり，專業的經營が許されず，農業 の副業的經營の性格を持つている. 從つて筑業は俗に「ヤナ仲間」と稱す る共同經營を通則とするのも主經營上の危險性を免かれるをるである。 魞・築共飞坐農坐漁的經營であるが，筑漁業は魞漁業より一層農業への從 屬的雗䋆が强く, その副業的經營が濃厚であり, 且つ筑漁業者は中農以上 の富有農家の共同經營であつて, 魶業者とその性格を異にしている. 又舊 來, 筑漁場の賃借料は部落會との交涉によつて成立しそ. との場合, 梁仲 間の 1 人社漁業會長であり, 又部落會長である事も亦り, 他から競争入札 する餘地がなく，特權的封䞳性の强い存在でもあつたととも築漁業の特色 の一つで每る。

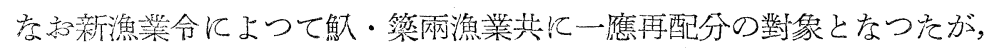

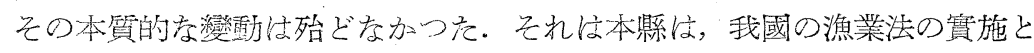
共に，既に明治 35 年漁業取縍規則を制定し，資源の保護育成上漁業權を 設定し, 制限を强化した爲, 今回は特記すべを變革は見られなかつなので ある。

\section{註及び參考交獻}

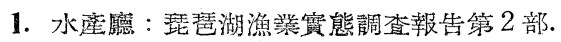

2. 冈田秀雄：魞の研究人交地理 3 卷 4 號 